\title{
REQUEST FOR A CHANGE IN ARTICLE 40 OF THE CODE Z.N.(S.)2250
}

\section{By Marian H. Pettibone (National Museum of Natural History, Washington D.C. 20560, U.S.A.)}

I am asking the International Commission on Zoological Nomenclature to seriously consider changing Article 40 of the Code concerning the conservation of a family-group name after 1960 and making it retroactive. A family-group name should reflect the name and meaning of the type genus. If the name of the type genus goes into synonymy, the family name should also be replaced, with the exception of a name long established in the literature and whose meaning is well understood. I cite the following case in Polychaeta as a basis for my objection to the rule.

In the NEREIDIDAE, Micronereis variegata Claparède, 1863 has long been considered to be an aberrant member of the family and referred to often in the literature because of its unique features. Four species were subsequently added to Micronereis.

Notophycus minutus Knox \& Cameron, 1970 was placed in a new family NOTOPHYCIDAE. Phyllodocella bodegae Fauchald \& Belman, 1972 was added to this family.

In a revisionary study on the species of Micronereis, Banse, 1977, Essays on Polychaetous Annelids, Allan Hancock Foundation, referred Notophycus and Phyllodocella to Micronereis and placed them in a subfamily NOTOPHYCINAE, with type genus Micronereis (syn.: Notophycus) following Article 40.

We now have a subfamily with the single genus Micronereis and eight species (according to a recent revisionary study by Hannelore Paxton). It is only logical that it should be called MICRONEREIDINAE, reflecting the well-known genus Micronereis, and not Notophycus, based on a misunderstanding of the diagnostic characters and not well-known.

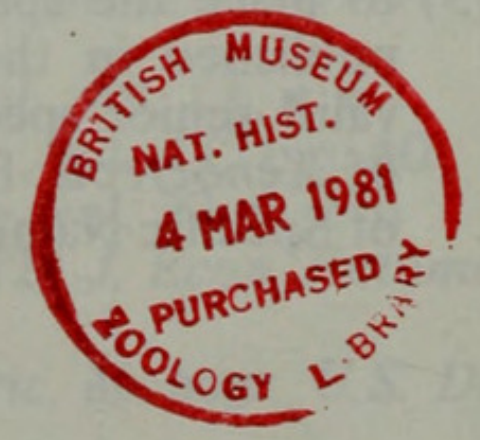





\section{$2 \mathrm{BHL}$ Biodiversity Heritage Library}

Pettibone, Marian H. 1981. "Request For A Change In Article 40 Of The International Code Of Zoological Nomenclature." The Bulletin of zoological nomenclature 38, 76-77. https://doi.org/10.5962/bhl.part.8167.

View This Item Online: https://www.biodiversitylibrary.org/item/44480

DOI: https://doi.org/10.5962/bhl.part.8167

Permalink: https://www.biodiversitylibrary.org/partpdf/8167

\section{Holding Institution}

Natural History Museum Library, London

\section{Sponsored by}

Natural History Museum Library, London

\section{Copyright \& Reuse}

Copyright Status: In copyright. Digitized with the permission of the rights holder.

License: http://creativecommons.org/licenses/by-nc-sa/3.0/

Rights: https://biodiversitylibrary.org/permissions

This document was created from content at the Biodiversity Heritage Library, the world's largest open access digital library for biodiversity literature and archives. Visit BHL at https://www.biodiversitylibrary.org. 